\title{
Filamentous Fungi Isolated from Brazilian Semiarid Tolerant to Metallurgical Industry Wastes: An Ex Situ Evaluation
}

\author{
Flavio Manoel Rodrigues da Silva Júnior ${ }^{1 *}$ and Sônia Valéria Pereira ${ }^{2}$ \\ ${ }^{1}$ Laboratório de Ensaios Farmacológicos e Toxicológicos; Universidade Federal do Rio Grande; Rio Grande - RS - \\ Brasil. ${ }^{2}$ Instituto Tecnológico de Pernambuco; Recife - PE - Brasil
}

\begin{abstract}
The purpose of this study was to assess the impact of metallurgical industry wastes on the semiarid soil microbiota using physico-chemical and microbiological parameters, highlighting the filamentous fungi assembly. Soil samples were collected in an area of industrial waste deposit contaminated with lead and mixed with natural soil (control soil) in seven different concentrations $(0,7.5,15,30,45,60$ and 100\%). The results showed alterations on the physico-chemical properties of the soil treated with industrial wastes, with a gradate increase of the soil's pH (5.6-

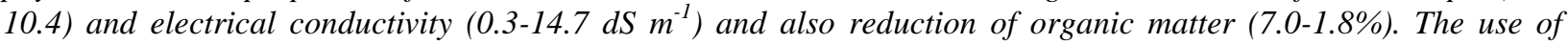
microbiological parameters (fungal richness and diversity, $\mathrm{CO}_{2}$ emission, and the carbon on the microbial biomass) enabled the identification of alterations on the microbial community due to stress caused by the exposure to industrial wastes, despite the presence of Thielavia, Chaetomium and Aspergillus tolerant to high concentrations of the scoria. Therefore, these filamentous fungi could be used in biomonitoring and bioremediation studies in the soils contaminated by industrial wastes.
\end{abstract}

Key words: Chaetomium, microbial activity, contaminated soils, filamentous fungi, Lead

\section{INTRODUCTION}

The soil can be defined as the layer that has high chemical and biological activity, located on a rock-matrix, consisting of minerals, organic matter, water, air, roots of plants and microorganisms, including algae, bacteria, virus, protozoa and fungi (Stenberg 1999). These microscopic organisms have different ecological roles, from primary producers to decomposers of organic matter, thus forming a complex microbial community. When considering beyond the biotic components (community), the abiotic factors, it is then a self-sustaining ecological unit, called ecosystem. In this compartment, the energy flows through the trophic levels and nutrients are regenerated. Thus, fungi have fundamental importance in this system, since they act in nutrient cycling, being the main decomposers of vegetable material (Eggins and Allsopp 1975; Atlas and Bartha 2002).

Although studies estimate the fungal diversity as more than one million five hundred thousand species, this diversity is critically endangered, mainly due to anthropogenic activities, including soil contamination by heavy metals, in which the increased toxicity causes drastic changes the functioning of ecosystems (Gilmore 2001; Kirk et al. 2004). The use of soil quality indicators allows a detailed investigation of the environment, seeking improvements in their conservation and sustainability. Studies have been conducted on the

*Author for correspondence: f.m.r.silvajunior@gmail.com 
microorganisms from the degraded areas due to their role in the degradation and recycling of organic matter and ability to respond quickly to environmental changes. Microbial activity reflects the sum of factors regulating the transformation nutrients (Stenberg 1999; Zilli et al. 2003).

Zilli et al. (2003) emphasized the importance of studies about microbial diversity, both functional and structural, to determine the recovery of priority areas. Soil respiration and microbial biomass have been used as sensitive indicators of metabolic stress due to the ability to reflect the changes in environments subjected to stressful conditions by excessive contaminants. The reduction in microbial biomass after a stage of dormancy and increased release of $\mathrm{CO}_{2}$ and can be interpreted as mechanisms of resistance to microbial toxicity of pollutants (Insam et al. 1996; Chew et al. 2001; Filip 2002; Andrade and Silveira 2004).

Heavy metals are naturally occurring substances in the environment, but when its concentration reaches hazardous levels can cause damage to humans and the environment. Although in recent years, the number of studies concerning the impact of heavy metals in the organisms has increased, when considering semiarid soil, including Brazilian semiarid soils, the number of studies is rarely. Thus, the investigation of microbial parameters may be a promising alternative to monitoring of degraded areas.

The aim of this study was to evaluate the toxic effect of adding a lead-rich waste from a metallurgical industry in the Brazilian semiarid soil microbiota, evaluating possible changes in microbial biomass carbon, basal respiration and fungal diversity and highlighting lead-tolerant fungi.

\section{MATERIAL \& METHODS}

The natural soil and lead-rich solid industrial waste samples were collected on the perimeter of a metallurgical industry, located in Belo Jardim (Pernambuco state, Brazil). The natural soil $(\mathrm{Pb}$ content - $209 \mathrm{mg} \mathrm{kg}^{-1}$ ) was collected from Morro do Gavião, located $1 \mathrm{Km}$ from the industrial plant and elevation above the industry. Lead-rich solid industrial waste $\left(1835 \mathrm{mg} \mathrm{kg}^{-1}\right)$ was collected in a landfill located within the industry, after the decanting process of lead compounds and neutralization of sulfuric acid used in the batteries manufacture. Natural soil samples and lead-rich solid industrial waste were mixed for the treatments with intermediate concentrations of contaminated soil. The waste was mixed with natural soil in seven concentrations: $0,7.5,15,30$, 45, 60 and $100 \%$.

Following parameters were evaluated in duplicate: humidity $\left(105^{\circ} \mathrm{C}\right)$, field capacity and organic matter $\left(550^{\circ} \mathrm{C}\right)$, and in triplicate: electrical conductivity (soil: $\mathrm{H}_{2} \mathrm{O}, 1: 2$ after $24 \mathrm{~h}$ ), $\mathrm{pH}$ (soil: $\mathrm{H}_{2} \mathrm{O}, 1: 2$ ), microbial biomass carbon, basal respiration and fungal diversity and density. The microbial biomass was estimated by the method of Jenkinson and Powlson (1976). Briefly, $22.5 \mathrm{~g}$ of soil samples were subjected to chloroform fumigation (ethanol-free) and left in the dark for $24 \mathrm{~h}$. After fumigation, the soil sample was reinoculated with non-fumigated soil (2.5 g; 1:9, inoculum: fumigated soil). Another soil fraction $(25 \mathrm{~g})$ was not fumigated with chloroform. The samples fumigated and non-fumigated were incubated for 14 days in closed containers in 10 $\mathrm{mL}$ of $0.5 \mathrm{~N} \mathrm{KOH}$. After this period, $\mathrm{CO}_{2}$ was determined by $\mathrm{KOH}$ titration using $\mathrm{HCl} 0.1 \mathrm{~N}(\mathrm{pH}$ 8.3 and 3.7) following the method of De-Polli and Guerra (1996). In order to avoid overestimate the amount of carbon, microbial samples with high respiration rate, following formula was used:

$\mathrm{MC}=[\mathrm{F} /(\mathrm{NF}-\mathrm{RR})] / \mathrm{kc}$

where $\mathrm{MC}$ is microbial carbon, $\mathrm{F}$ represents the carbon from $\mathrm{CO}_{2}$ released in fumigated soil samples; NF represents the carbon from $\mathrm{CO}_{2}$ released in the non-fumigated soil, RR is the basal respiration rate and $\mathrm{kc}$ is the conversion factor (0.45) (Wardle 1994).

The basal respiration was evaluated according to Grisi (1997). Briefly, soil samples (100 g) were incubated in the dark for 14 days in a hermetically sealed container containing $1 \mathrm{~mL}$ of $0.5 \mathrm{~N} \mathrm{KOH}$ After this, it was titrated using $\mathrm{HCl}(0.1 \mathrm{~N})$ using phenolphthalein and metilorange. $\mathrm{CO}_{2}$ values were expressed as $\mu \mathrm{g} \mathrm{CO}_{2} \mathrm{~g}^{-1}$ dry soil.

Microbial density was estimated for fungal isolates using the serial dilutions procedure following Warcup (1950). Briefly, $25 \mathrm{~g}$ of soil were diluted in $225 \mathrm{~mL}$ of sterile distilled water. For successive dilutions, suspensions $(10 \mathrm{~mL})$ were transferred to bottles containing $90 \mathrm{~mL}$ of sterile distilled water. For each dilution, $0.2 \mathrm{~mL}$ was seeded onto plates containing Potato Dextrose Agar (PDA) medium. The plates were incubated at $25^{\circ} \mathrm{C}$ in the dark for three days and colonies 
were counted as colony forming units per gram of soil (CFU g-soil). The fungal diversity was assessed from the identification of filamentous fungal isolates to genus level following Fenell et al. (1965) and Domsch et al. (1980). Data were evaluated by the ANOVA and when necessary were compared by Tukey test at 5\% significance. The fungal diversity was used as Shannon index.

\section{RESULTS AND DISCUSSION}

The $\mathrm{pH}$ values increased after the addition of leadrich solid industrial waste. The natural soil was of slightly acidic character as control ( $0 \%$ treatment), whereas treatment with the addition of waste had alkaline $\mathrm{pH}$, due to the addition of lime used to neutralize the sulfuric acid-rich waste (Table 1). The electrical conductivity (EC) due to the treatment 30\% was high, which exceeded the detection limit of the equipment. Similarly $\mathrm{pH}$ values were significantly high with the increase of waste. The organic matter contents were negatively correlated with the waste concentration $(\mathrm{r}=-0.94, \mathrm{p}=0.001)$ (Table 1). This low percentage of organic matter in the treatment with lead-rich waste was closely related to the high percentage of the mineral fraction of the waste generated in the processing industry.

Table 1 - Mean values of $\mathrm{pH}$, Electrical Conductivity $(\mathrm{EC})$, organic matter $(\mathrm{OM})$, and $\mathrm{CO}_{2}(1)$ of the soil samples contaminated by a lead waste.

\begin{tabular}{|c|c|c|c|c|}
\hline Treatment & pH & $\begin{array}{c}\text { Electrical } \\
\text { condutivity } \\
\left(\mathbf{d S ~} \mathbf{m}^{-1}\right)\end{array}$ & $\begin{array}{c}\text { Organic } \\
\text { Matter } \\
(\%)\end{array}$ & $\begin{array}{c}\mathrm{CO}_{2} \\
\text { emission }^{(1)} \\
\left(\mu \mathrm{gCO}_{2} \mathrm{~g}^{-1}\right. \\
\text { dry soil })\end{array}$ \\
\hline $0 \%$ & $5.6 a$ & $0.3 a$ & $7.0 \mathrm{a}$ & $3.42 \mathrm{a}$ \\
\hline $7.5 \%$ & $8.5 b$ & $6.6 b$ & $6.6 \mathrm{a}$ & $9.72 b$ \\
\hline $15 \%$ & $9.6 \mathrm{c}$ & $14.7 \mathrm{c}$ & $5.7 \mathrm{a}, \mathrm{b}$ & $11.77 \mathrm{c}$ \\
\hline $30 \%$ & $9.8 \mathrm{c}, \mathrm{d}$ & - & $5.2 b$ & $12.47 \mathrm{c}$ \\
\hline $45 \%$ & $9.9 \mathrm{c}, \mathrm{d}$ & - & $3.8 \mathrm{c}$ & $12.79 \mathrm{c}$ \\
\hline $60 \%$ & $10.3 \mathrm{~d}$ & - & $1.85 \mathrm{~d}$ & $9.35 b$ \\
\hline $100 \%$ & $10.4 \mathrm{~d}$ & - & $1.8 \mathrm{~d}$ & $6.94 d$ \\
\hline
\end{tabular}

- Measures with values above the detection limit of the equipment; Means followed by the same letter in the column do not differ by Tukey test at $5 \%$ probability, (1) the square root of the values

The $\mathrm{CO}_{2}$ emission values decreased in the treatment without contamination compared to other treatments (Table 1). Similar results were observed by Leita et al. (1995) and Khan and Scullion (2002), where the presence of heavy metals caused an increase in respiration rate, indicating an increased metabolic burden in response to the stress. The increase in $\mathrm{CO}_{2}$ emission until the treatment $45 \%$ and the significant decline in the treatments 60 and $100 \%$ indicated a tolerance limit to stress caused by increasing the concentration of the waste.

The microbial carbon decreased with the addition of lead-rich waste in the soil $(r=-0.76, p=0.001)$ (Fig. 1). This profile has already been reported in the studies such as by Konopka et al. (1999) and Andrade and Silveira (2004), where biomass was negatively correlated with the concentration of metals in the soil and suggested the high toxicity of this waste on soil microbial community. Fungal density values decreased with increasing concentration of lead-rich solid industrial waste, while treatment (100\% waste) showed no growth of filamentous fungi (Table 2). A similar effect was reported by Konopka et al. (1999) studying soils contaminated by lead.

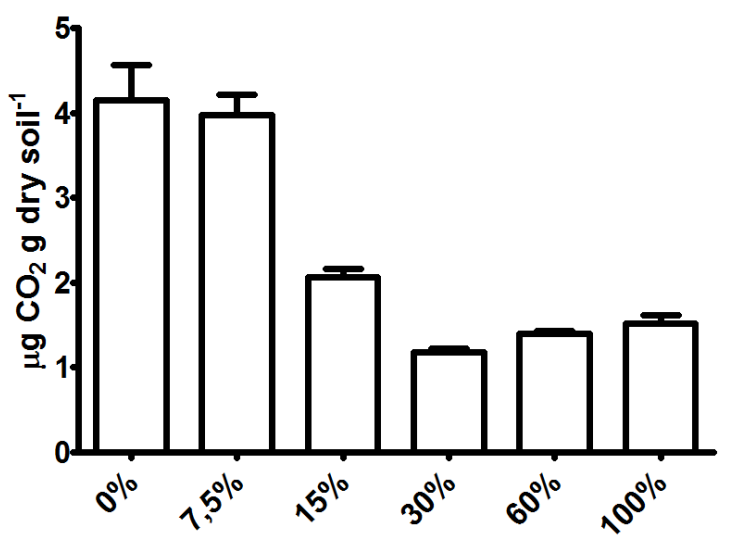

Figure 1 - Microbial biomass carbon in soil samples contaminated by a lead waste.

The addition of lead-contaminated waste affected the fungal richness (represented by the number of taxa) and diversity (Table 2) $(\mathrm{r}=-0.77, \mathrm{p}=0.03$ and $r=-0,74, p=0.04$ ), with the largest diversity index in the treatment $7.5 \%$. This could be related to what Connell (1978) called "intermediate disturbance hypothesis". This hypothesized that the environments with a moderate level of disturbance created mosaics of habitats, which increased environmental heterogeneity and biological diversity. The lowest diversity index of treatment $0 \%$ compared to $7.5 \%$ could be a result of the dominance of the genus Aspergillus in natural soil samples ( $64 \%$ of total), usual pattern found in the mature communities (Atlas and Bartha 2002). After the treatment $15 \%$, only fungi 
of the genera Thielavia, Aspergillus and Chaetomium were isolated from the soil samples. Da Silva Júnior and Pereira (2007) studying filamentous fungi from the soils contaminated by lead in the same region highlighted these three genera as tolerant to lead. The tolerance was confirmed by exposing these cultures to different concentrations of lead nitrate.

Table 2 - Genera richness and Shannon diversity $(\mathrm{H})$ of filamentous fungi isolated from soil samples contaminated by a slag rich in lead.

\begin{tabular}{cccccc}
\hline Treatment & Genus $^{(\mathbf{1})}$ & $\begin{array}{c}\text { Genus } \\
\text { number }\end{array}$ & Richness & Diversity & $\begin{array}{c}\text { Density } \\
\text { (ufc g-1dry soil) }\end{array}$ \\
\hline $0 \%$ & $\mathrm{As}, \mathrm{Pe}, \mathrm{Al}, \mathrm{Th}, \mathrm{Fu}, \mathrm{Cu}, \mathrm{Pr}, \mathrm{Sp}, \mathrm{Ph}$ & 9 & 2.2 & 1.3 & 13667 \\
$7.5 \%$ & $\mathrm{As}, \mathrm{Pe}, \mathrm{Al}, \mathrm{Ch}, \mathrm{Ps}, \mathrm{Hu}$ & 6 & 1.8 & 1.7 & 4333 \\
$15 \%$ & $\mathrm{As}, \mathrm{Th}, \mathrm{Ch}$ & 3 & 1.1 & 1.1 & 1167 \\
$30 \%$ & $\mathrm{Th}$ & 1 & 0 & 0 & 1667 \\
$45 \%$ & $\mathrm{As}, \mathrm{Ch}$ & 2 & 0.7 & 0.7 & 833 \\
$60 \%$ & $\mathrm{As}, \mathrm{Ch}$ & 2 & 0.7 & 0.7 & 500 \\
$100 \%$ & ${ }^{(2)}$ & 0 & 0 & 0 & 0 \\
\hline
\end{tabular}

(1) Abbreviations of genera. (As) Aspergillus (Micheli 1729); (Pe) Penicillium (Link 1809); (Al) Alternaria (Nees, 1817); (Th) Thielavia (Zopf 1876); (Fu) Fusarium (Link ex Grey 1821), (Cu) Curvularia (Boedijn 1933), (Pr) Periconia (Tode 1791); (Sp) Spegazzinia (Speg 1879); (Ph) Phoma (Saccardo 1880); (Ch) Chaetomium (Kunze 1817); (Ps) Pestalotiopsis (Steyaert 1949), (Hu) Humicola (Traen 1914). (2) In the treatment 100\% there was no presence of any filamentous fungus.

The reason why the fungi of the genera Thielavia, Chaetomium and Aspergillus are more tolerant to lead-rich solid waste is still unclear. However, Chew et al. (2001) and Franco et al. (2004) reported that some microorganisms have physiological adaptations to tolerate and even interfere in the availability of the metals. Bruins et al. (2000) summarize six mechanisms of resistance of microorganisms to the metals: permeability barrier, active transport of metal out of the cell, intracellular sequestration by binding the proteins, extracellular sequestration, enzymatic reduction and reducing the vulnerability of cellular targets to metal ions. Vido et al. (2001) mentioned that eukaryotic cells could remove toxic ions by chelation with low-molecular-weight oligopeptides. Thus, it was likely that fungal tolerant to lead in this stud was due to some of these strategies to minimize the impact caused by high concentrations of lead. This should be investigated further in its physiological and biochemical aspects as well as ecological for use in environmental monitoring studies.

\section{REFERENCE}

Andrade SAL, Silveira APD. Biomassa e atividade microbianas do solo sob influência de chumbo e da rizosfera da soja micorrizada. Pesqui Agropec Bras. 2004; 39(12): 1191-1198.
Atlas RM, Bartha R. Ecología microbiana y Microbiología Ambiental. Madrid: Pearson Educación; 2002.

Bruins MR, Kapil S, Oehne FW. Microbial Resistance to metal in the Environmental (Review). Ecotox Environ Saf. 2000; 45: 198-207.

Chew I, Obbard JP, Stanforth RR. Microbial cellulose decomposition in soils from a rifle range contaminated with heavy metals. Environ Pollut. 2001; 111: 367-375.

Connel JH. Diversity in tropical rain forests and coral reefs. Science. 1978; 199(24): 1302-1310.

Da Silva Júnior FMR, Pereira SV. Ecologia e fisiologia de fungos filamentosos isolados de solo contaminado por metais pesados. Rev Bras Bioci. 2007; 5(2): 903905.

De-Polli H, Guerra JCM. Biomassa microbiana: perspectivas para o uso e manejo do solo. In: Alvarez VHV, Fontes MP. O solo nos grandes domínios morfoclimáticos do Brasil. Viçosa, Soc Bras Ciência do Solo. 1996: p.552-564.

Domsch KH, Gams W, Anderson TH. Compendium of soil fungi, Vol. II. London: Academic Press. 859 p. 1980.

Eggis, HOW, Allsopp D. Biodeterioration and Biodegradation by Fungi. In: Smith JE, Berry DR. The filamentous fungi - Industrial Mycology. Glasgow: Univ. of Strathdyde; 1975. p. 301-319.

Fennell DI, Lillehoj EB, Kwoler WF. Aspergillus flavus and other fungi associated with inseci-damaged fild corn. Cer Chem. 1965; 52(3): 314-321.

Filip Z. International approach to assessing soil quality by ecologically related biological parameters. Agri Ecosys Environ. 2002; 188: 169-174. 
Franco LO, Maia RCC, Porto ALF, Messias AS, Fukushima K, Campos-Takaki GM. Heavy Metal biosorption by Chitin and Chitosan isolated from Cunninghamella elegans (IFM 46109). Braz J Microbiol. 2004; 35: 243-247.

Gilmore EA. Critique of Soil Contamination and Remediation: The Dimensions of the Problem and the Implications for Sustainable Development. Bull Sci Technol Soc. 2001; 21(5): 394-400.

Grisi BM. Temperature increase and its effect on microbial biomass and activity of tropical and temperate soils. Rev Microbiol. 1997; 28: 5-10.

Insam H, Hutchinson TC, Reber HH. Effects of heavy metal stress on the metabolic quotient of the soil microflora. Soil Bio Biochem. 1996; 28:691-694.

Jenkinson, DS, Powlson, D.S. (1976): The effects of biocidal treatments on metabolism in soil. V. Method for measuring soil biomass. Soil Bio Biochem. 1976; 8: 209-213.

Khan M, Scullion J. Effects of metal $(\mathrm{Cd}, \mathrm{Cu}, \mathrm{Ni}, \mathrm{Pb}$ or $\mathrm{Zn}$ ) enrichment of sewage-sludge on soil microorganisms and their activities. Appl Soil Ecol. 2002; 20: $145-155$.

Kirk JL, Beaudette LA, Hart M, Moutogles P, Klironomos JN, Lee $\mathrm{H}$, et al. Methods of studying soil microbial diversity. J Microbiol Meth. 2004; 58:169-188.
Konopka A, Zakharova T, Bischoff M, Oliver L, Nakatsu C, Turco RF. Microbial Biomass and Activity in Lead Contaminated Soil. Appl Environ Microbiol. 1999; 65(5): 2256-2259.

Leita L, De Nobili M, Muhlbachova G, Mondini C, Marchiol L, Zerbi G. Bioavaliability and effects of heavy metals on soil microbial biomass survival during laboratory incubation. Bio Fert Soil. 1995; 19: 103-108.

Stenberg B. Monitoring soil quality of arable land: microbiological indicator. Soil Plant Sci. 1999; 49: 263-272.

Vido K, Spector D, Lagniel G, Lopez S, Todelano MB. A Proteome Analysis of the Cadmium Response in Saccharomyces cerevisiae. J Biol Chem. 2001; 276: 8469-8474.

Warcup JH. The Soil plate method for isolations of fungi from soil. Nature. 1950; 166: 117-118.

Wardle DA. Metodologia para quantificação da biomassa microbiana do solo. In: Hungria, M. ; Araújo, R. S. (Ed.) Manual de métodos empregados em estudos de microbiologia agrícola. Brasília: EMBRAPA. 1994; 419-436.

Zili JE, Rumjanek NG, Xavier GR, Coutinho HLC, Neves MCP. Diversidade Microbiana como indicador de qualidade do solo. Cad Ciên Tecnol. 2003; 20: 391-411. 